\title{
Design of Management on School Literacy Program: A Perspective from Indonesian Schools
}

\author{
Netti Lastiningsih $^{1, *}$, Yatim Riyanto ${ }^{1}$, Toho C Mutohir ${ }^{1}$, Karwanto $^{1}$, Mudjito ${ }^{1}$, Sugi Hartono ${ }^{2}$ \\ ${ }^{1}$ Management Education, Universitas Negeri Surabaya, Surabaya, Indonesia \\ ${ }^{2}$ Mathematics Education, Universitas Negeri Surabaya, Surabaya, Indonesia
}

Received October 9, 2019; Revised November 12, 2019; Accepted November 23, 2019

Copyright $(2019$ by authors, all rights reserved. Authors agree that this article remains permanently open access under the terms of the Creative Commons Attribution License 4.0 International License

\begin{abstract}
This study aims to describe a design of management of school literacy programs (SLP) at a Junior High School, East Java, Indonesia and describe teachers' and students' responses about SLP in the school. This method is a descriptive-explorative research which collects data from questionnaires and unstructured interviews. This study used the SLP management design through sequential stages that need assessment, planning, organizing, actuating or implementation, and controlling (monitor and evaluation). Data from 20 students and 5 teachers were analyzed by percentage and qualitative analysis including data reduction, data display, and conclusion drawing or verification. The results of the study illustrate the SLP management design that is quite effective because it involves all the components in the school and selected management behaviors tend to be supportive-facilitative. Teachers and students tend to respond positively to the SLP although there are several aspects that need to be improved such as the use of technology and the productivity of the work of students or teachers.
\end{abstract}

Keywords School Literacy, Design of SLP, Supportive, Facilitative

\section{Introduction}

Some international surveys of PISA (Program for International Student Assessment), TIMSS (Trends in International Mathematics and Science Study), and PRLS (Progress in International Reading Literacy Study) report on insignificant improvements of Indonesian students in mathematical literacy, science literacy, reading literacy. The score of PISA 2015 in mathematics field is 397, which is below the overall average score of 493 . In science literacy, it shows an average score of 403 , which is also below the overall average score of 493 (OECD, 2015). In addition, TIMSS result also shows that Indonesian fourth grade students get a score of 397 for math and science under an average of 500 (Mullis, et.al, 2016). The score of the PIRLS of fourth grade students in Indonesia in 2011, on the other hand, it also has 428 , which is below the standard average of 500 (TIMSS \& PIRLS 2012). This condition triggers Indonesian government to make changes to the curriculum in 2013 known as "Curriculum 2013" so that the quality of Indonesia's generation can be superior and have competitiveness at international level.

In line with Siswono, et al, 2018, the implementation of the 2013 curriculum, the Ministry of Education and Culture also launched programs that support the curriculum, namely: integration of strengthening character education; school literacy movement (SLM); integrating 21 st century skills, namely 4C (creative, critical thinking, communicative, and collaborative); integrating HOTS (higher order thinking skills) or higher-order thinking skills. The four programs are the responsibility of the school to develop and implement them in the classroom or outside the classroom. School Literacy Program (SLP) is a program launched by the Ministry of Education and Culture through Ministerial Regulation No. 23 of 2015 (Permendikbud No. 23, 2015) to nurture the attitude of noble character to children through reading activities. Reading is believed to be a reflective, analytical, and critical skill, leading to the development of other fields of ability such as math or science. The ability to read is related to the ability of mathematics and science (Imam, 2016; Armbruster, 1992). This present study aims to describe a design of SLP management implemented by a principal of a Junior high school at East Java province, Indonesia.

\section{Materials}

\subsection{School Literacy Program (SLP)}

SLP is a program to strengthen the movement of 
character development. One of the activities in the program is a 15 minute activity of reading a non-learning book before the time of study begins. This activity is conducted to foster learners' interest in reading and improve reading skills so that their knowledge increase. The reading material contains the values of character, in the form of local, national, and global wisdom that is delivered according to the stage of development of learners (Kemendikbud, 2017). School Literacy in the SLP context is the ability to access, understand, and use something intelligently through various activities, including reading, viewing, listening, writing, and / or speaking (Retnaningdyah, et al., 2016). The general purpose of SLP is to develop the character of learners through the culture of the school literacy ecosystem embodied in the SLP so that they become lifelong learners. Meanwhile, the specific objectives of SLP such as to foster a culture of literacy in schools, to increase the capacity of citizens and the school environment for literacy, and make the school a fun and child-friendly learning park so that schoolchildren can manage knowledge.

The implementation of SLP consists of 3 stages, namely: (1) habituation: the growth of reading interest through such as activities 15 minutes reading, daily reading journal, creating a text-rich environment (Permendikbud No. 23, 2015); (2) development: improving literacy skills through enrichment activities; and (3) learning: improving literacy skills in all subjects: using enrichment books and reading strategies in all subjects. The implementation of the school literacy movement depends on the role of the principal in managing the program and mobilizing students, teachers, and all elements of the school. Survey results of principals of junior high schools in Sidoarjo district, East Java, show that the management of SLP is still not optimal, especially in the development and learning stage. All schools have a 15-minute reading program at the beginning, during, and end of learning (Lastiningsih et al, 2017). There are still shortcomings and limitations in design and management. For example, there are $79.2 \%$ of schools that have not yet completed the source of learning texts in the school room, corridor, or in the school area. There are $62.5 \%$ of principals and administrative staff who have not been involved in the program.

\subsection{Management of SLP}

Since SLP is relatively new for Indonesian schools compared to other programs, requiring planned, systematic, and effective management to become a culture within the school environment. The management of the program requires an effective design as it involves teachers, education personnel, students, and principals (Siswono, et al. 2018, January). The principal as a top manager, in this case, needs to plan, organize, actuate, and control the program that has been designed (Hariri et al., 2016). The principal should follow the management theories although without his realizing it. The theory used can be a classical, neo-classical, or modern theory (Kompri, 2015). The classical theory is based on the view that organizations work in a logical and rational process with a scientific approach and follow the structure or anatomy of an organization. Neo-classical theory known as the theory of human relations management based on the human view is social creatures that actualize themselves. The modern theory uses a system approach that views the organization as a system that is united and directed from the components that are interrelated. In a school in its implementation, the principal's management model can be recognized according to several theories above, including its management functions. Management functions will also be recognized in terms of planning, organizing, actuating, and controlling (Hariri, et al., 2016). Planning is the process of setting goals, policies, procedures and programs of an organization. Organizing is the act of seeking effective behavioral relationships between the individuals involved. Actuating is an effort to realize the results of planning and organizing an organization. Controlling is an activity to observe and measure all operational activities and achievement of results by comparing according to established standards.

Principals as leaders and managers in a school can be identified from how the nature of leadership, leadership skills, behavior and leadership style held by the principals. Overton (Syafaruddin, 2010) describes the three leadership skills (managerial) a leader must possess, namely technical skill, human skill, and conceptual skills. Technical skill is the ability to use tools, procedures, or techniques according to the field. Humanitarian skills are the ability to work with others, understand the circumstances and situations, be able to motivate others, individuals and groups. Conceptual skills are the mental ability to coordinate and integrate all relationships, organizational goals, and activities. The nature of a good leader is honest, knowledgeable, courageous and able to make decisions, trustworthy, be initiative, wise, firm, fair, exemplary, resilient, loyal, selfless, enthusiastic, sympathetic and humble (Syafaruddin, 2010). Leader behavior according to Robbins and Hersey \& Blanchard (Syafaruddin, 2010) is (1) directive, (2) supportive, (3) facilitative, and (4) achievement-oriented. Directive behavior is indicated by the leader telling what and when something is done by the employee and there is no participation in decision making. Supportive behavior is characterized by managers being employees' companions and showing their interest. Facilitative behavior is pointed out that leaders makes easier to telling suggestions and engaging employees in decision making. Achievement-oriented behavior is the leader divides the contribution of goals and shows the belief that employees are able to achieve goals.

Besides that, according to Timpe (in Syafaruddin, 2010) that leadership style is autocratic, democratic, and free control (laissez faire). The autocratic style emphasizes all 
the authority (rights and powers) of doing something centered on the manager. This style relies on personal formal authority in the position of manager-oriented task and production. These democratic or participatory styles emphasize the dissemination or sharing of responsibilities, the empowerment of members of the organization, and cooperate well. This style considers the wishes and suggestions of its members. The free-control style emphasizes that leaders make little effort to exercise control or influence over their group members. Members are given goals but left to use their own way to achieve them.

Based on some theories above, we modified of Hariri et al (2016) theory for the design of management on this SLP. We added some stages, such as need assessment, planning, organizing, actuating, and controlling.

\section{Methods}

This descriptive-explorative research was carried out by collecting data about the responses of teachers and students at the school. This study used the SLP management design through sequential stages that need assessment, planning, organizing, actuating or implementation, and controlling (monitor and evaluation).

Figure 1 summarizes the design of SLP implemented in the school subject from identifying need assessment until monitoring.

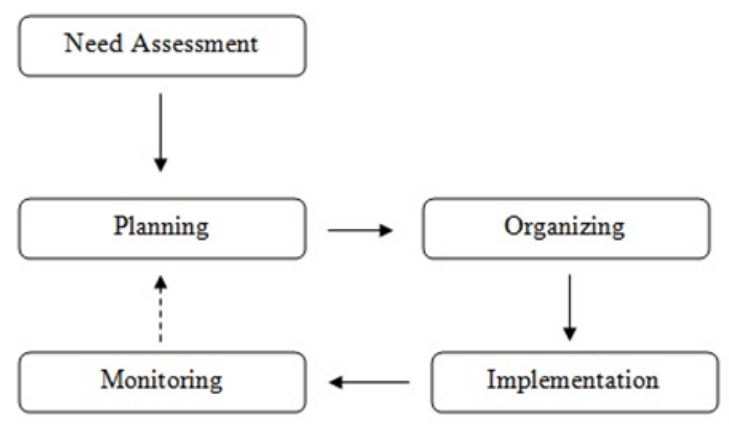

Figure 1. Design of the Implemented SLP

Data collection was done by questionnaire and unstructured interview (Siswono, 2008). The questionnaire was given to 20 students of grade nine. It consists of 20 statements with a choice of "Yes" and "No". The unstructured interviews were conducted for 5 teachers, each consisting of one vice principal, one head of the school literacy team, and 3 teachers from grade seven, eight, and nine. The interview focuses on the management of the principal's management that includes planning, organizing, actuating, and monitoring/evaluation, and leadership.

Analysis of questionnaire data was done by calculating the student's choice and categorizing in percentage. Qualitative data obtained through interviews include data reduction, data display, and drawing conclusion/verification (Miles \& Hubberman, 1992). Data reduction includes reducing and organising data, for example coding, writing summaries, and discarding irrelevant data. Data display is the process of collecting information organized on the basis of the categories or groupings required. Drawing conclusion or verification of data is the process of understanding and formulating the meaning of a series of data that have been presented, in the form that not only sees what is written, but more on understanding or interpreting about what is implied in the data that has been presented.

\section{Results}

\subsection{Management of SLP}

Implementation of literacy culture in schools follows the steps: preparation, implementation, monitoring and evaluation, and follow-up (Kisyani, et al, 2018). These stages need to be designed by principal as the responsible manager. Preparation involves preparing materials, human resources, and implementation strategies. Implementation is the operationalization of the things that have been prepared. Monitoring and evaluation is an activity to know the effectiveness of literacy activities that have been implemented. Follow-up refers to the things that need to be done next (preparation of advanced programs). Those four stages follow the stages proposed by Hariri, Karwan, and Ridwan (2016). Before designing SLP, the principal identifies problems and constraints and necessary needs analysis in fostering reading interest of learners by using the cause and effect diagram in figure 2 . The results of the analysis generally found that reading interest of students is still lacking. This becomes the first step to foster interest in reading by taking the policy to create a rich physical environment by the atmosphere of literacy, such as by creating a reading park. Preparation includes coordination meeting activities of school literacy team building, socialization, and preparation of infrastructure facilities. 


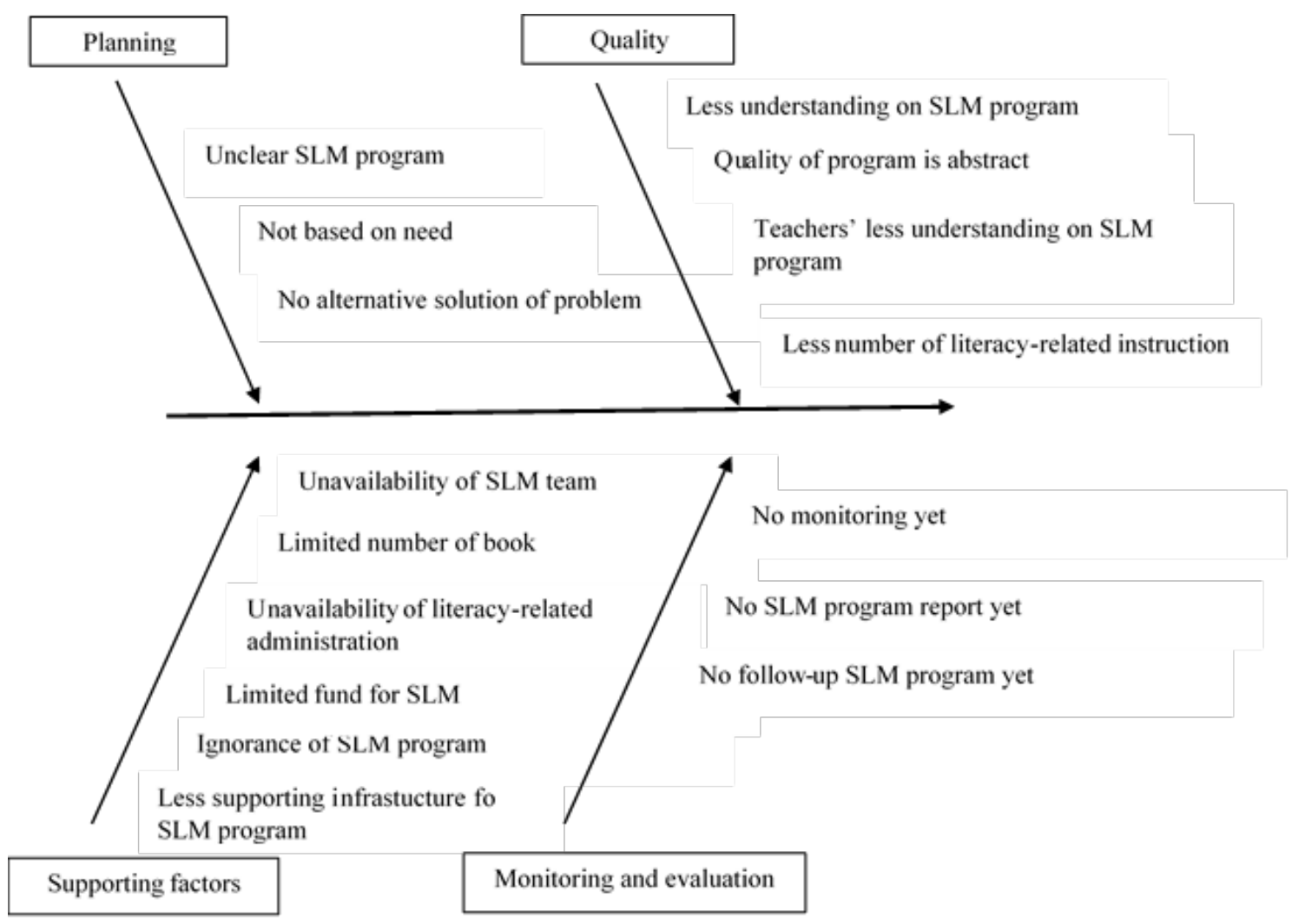

Figure 2. Cause and Effect Diagram the SLP

Thus, the school has arranged some related-programs, such as socialization of SLP for all school members, reading habit of 15 minutes before the first hour begins in each class accompanied by the teacher who teaches at the first hour, visiting the library by each subject, at least twice in one semester, reading a book of one month at least one book, aiming librarian as literacy coordinators at school, organizing competitions related to SLP, training for teachers to develop lesson plan related to literacy, publishing a book with a target of 3 books in a year written by both students and teachers, developing students' literacy through a technology-based literacy programs called Youth Scientific Work, Teacher Scientific Work Competition, and other competitions, cooperate with various parties for the development of school literacy.

Organizing is done principal by forming school literacy team. The School Literacy Team (SLT) consists of one English teacher, two Indonesian language teachers, and one Regional Language. This is because the teachers are book authors and are related to reading and competence in literacy. The literacy team is divided into a core team consisting of a chairman, vice chairmen, secretaries, and treasurers, and a support team called the working group comprising teachers and administrators of the OSIS (intra-school student organization). The working group includes a section on the procurement of works, competitions and creativity, as well as publications with each comprised of one teacher and two students. The procurement section of the work on duty periodically determines the theme of the work to be displayed in the corridor for a month. In addition, their another task is to collect students' work in the form of posters of learning or other works such as poetry or short story in cooperation with class literacy coordinator. The task of the section of competitions and creativity is to design and carry out competitions related to school literacy. The task of publishing section is to design the writing of books, guide writing, collect works, and prepare books ready for publication. Then, the socialization of all programs is done to teachers, employees, students, school committees and parents. For infrastructure, schools provide reading parks, fiction and non-fiction books outside of the books provided in the library.

The implementation SLP covers some programs as follows. (1) Socialization carried out in the first semester for all school members; (2) the habit of reading 15 minutes to do four times reading non-fiction books, magazines, or newspapers, in which teachers and principals also perform such activities; (3) A compulsory program for scheduling by the head of the library for each subject Lesson, at least twice in one semester; (4) Procurement of classroom reading corner, in which books are sourced from student and teacher contributions. In one lesson year, two class reading competitions with literacy, literature, and literature inventory were conducted; (5) The program of reading a book of one month at least one book. The activity is to make a single book's summary, in which the summary is given to the homeroom and promised at the end of the semester for habituation. This program is called SIJAMBU (student borrow one book) and SABUSASI (one student 
one book). These programs are included in the stage of habituation; (6) Procurement competitions such as a class corner, mural, writing contest, and literacy ambassador contests. This activity is included in the development stage; (7) Addition and upgrading of facilities for SLP, including book collection, internet network installations, library information computers, improved bookcase quality in school corridors.

Controlling that consist of monitoring and evaluation of SLP activities conducted by the principal and vice principal. Monitoring is routinely done every 3 months and some incidental activities are carried out during the event. The monitoring and evaluation use self-developed instruments by schools and also uses instruments from SLP guides. In general, the results are in accordance with the planning and reading habit has become the character of the students although there are still shortcomings. The shortcomings are like reading habits have not been up to one month, students prefer fiction books rather than textbooks, procurement of student work on the corridor takes more than one month, or teachers sometimes could not be a model of reading habit.

\subsection{Students' Response to SLP}

Based on Table 1 show that students generally respond positively to school literacy program. Students are enthusiastic about reading refraction (95\%), students want continuous activities (85\%), participating in class $(75 \%)$, interested in reading the reading campaign posters $(95 \%)$, posters on the important of healthy life style (100\%), writing journals of literacy program $(100 \%)$, academic literacy $(90 \%)$, and enthusiastic to join a big day with the theme of literacy $(80 \%)$. Students perceive that books are widely available in libraries (95\%), and they can use other sources for learning $(80 \%)$. According to the students, the teacher as a model in the class is not all of them $(65 \%)$, but the principal becomes the model and education personnel $(95 \%)$. Students also know that there is a literacy team at their school $(75 \%)$. The questionnaire also captured students' weaknesses in participating in corridors and other areas in schools (45\%), visiting libraries, reading booths, or reading parks $(45 \%)$, and non-academic follow-up activities (55\%).

Table 1. Students' responses

\begin{tabular}{|c|c|c|c|}
\hline No & Indicators & Yes & No \\
\hline 1 & I am very enthusiastic about the 15 minute reading activities conducted at the school. & $95 \%$ & $5 \%$ \\
\hline 2 & I want the 15 minute activity to read continuously. & $85 \%$ & $15 \%$ \\
\hline 3 & In my class, the teacher becomes a model in the 15 minute activity of reading by reading during the activity. & $65 \%$ & $35 \%$ \\
\hline 4 & $\begin{array}{l}\text { The principal and school personnel at my school became a model in the } 15 \text { minute reading activity by reading during } \\
\text { the activities. }\end{array}$ & $95 \%$ & $5 \%$ \\
\hline 5 & I know that there is a School Literacy Team (SLT) or a similar team formed by the principal. & $75 \%$ & $25 \%$ \\
\hline 6 & I participated in the procurement of text-rich materials emblazoned in the classroom. & $75 \%$ & $15 \%$ \\
\hline 7 & I participated in the procurement of text-rich materials emblazoned in corridors and other areas of the school. & $45 \%$ & $55 \%$ \\
\hline 8 & $\begin{array}{l}\text { I am interested in campaign posters about reading to broaden my understanding of any knowledge accessed from } \\
\text { school }\end{array}$ & $95 \%$ & $5 \%$ \\
\hline 9 & Every day I visit the library or reading corner in the class or reading area in school. & $45 \%$ & $55 \%$ \\
\hline 10 & $\begin{array}{l}\text { My school library already provides a variety of reading books (non-learning books: fiction and nonfiction) that I } \\
\text { need. }\end{array}$ & $95 \%$ & $5 \%$ \\
\hline 11 & In my opinion, posters about the habits of clean, healthy, and beautiful living in school are very important. & $100 \%$ & 0 \\
\hline 12 & Every time there is a reading activity, I write in a daily reading journal (write the title of the reading and page). & $90 \%$ & $10 \%$ \\
\hline 13 & $\begin{array}{l}\text { I am happy if my response Journal of reading reading books and / or textbooks is displayed in class and / or school } \\
\text { corridors. }\end{array}$ & $90 \%$ & $10 \%$ \\
\hline 14 & $\begin{array}{l}\text { I was active in various follow-up activities (from } 15 \text { minutes reading) in the form of generating oral and written } \\
\text { responses (part of a non-academic assessment). }\end{array}$ & $55 \%$ & $45 \%$ \\
\hline 15 & $\begin{array}{l}\text { I was active in various follow-up activities (from } 15 \text { minutes reading) in the form of generating oral and written } \\
\text { responses in the lesson (part of the integrated academic assessment in the subject value). }\end{array}$ & $80 \%$ & $20 \%$ \\
\hline 16 & I am committed to implementing and supporting the school literacy movement. & $100 \%$ & 0 \\
\hline 17 & I hope there is an appreciation of achievement in literacy activities on a regular basis. & $95 \%$ & $5 \%$ \\
\hline 18 & I am enthusiastic in following the academic activities that support the school literacy culture. & $100 \%$ & 0 \\
\hline 19 & I am enthusiastic in following the celebration activities of certain days with literacy theme. & $80 \%$ & $20 \%$ \\
\hline 20 & $\begin{array}{l}\text { I occasionally use a physical, social, affective, and academic environment with rich literacy-rich (print, visual, } \\
\text { auditory, digital) readings-beyond textbooks-to enrich knowledge in subjects. }\end{array}$ & $80 \%$ & $20 \%$ \\
\hline
\end{tabular}




\subsection{Teachers' Responses}

At the SLP planning stage, the results of interviews with five teachers stated that the SLP was well planned. SLT established by the school is in accordance with the competence of teachers. Programs designed by SLT fit the needs of students and schools. That is, the program is designed in accordance with the characteristics of students, namely the interest in reading students. The following is some excerpts of an interview on the SLT program that the teacher responded positively. "SIJAMBU and SABUSASI program is very appropriate because the program is in accordance with the condition of our current students who do not like reading textbooks." "The existence of a book publishing program can motivate students to produce work."

The thing that is still considered lacking in the planning stage is the socialization to the school community. The program is only planned at the beginning of the semester so that there are still school members who have not fully understood. This is indicated by the excerpts below. "The socialization of the literacy program is sometimes too close to the time if there is a particular event. Literacy programs are only known by SLT."'Socialization of SLT programs should be more intensive to all school residents, especially to homeroom and students."

At the organizing stage, the SLT is good because they involve teachers as well as students. However, the cooperation among individuals in SLT still lacks. The nature of individualism still exists and the team has not worked as delicately with its task. At the implementation stage, the teacher responds that the program has been implemented well, although there are still shortcomings. The short comings are among others that the reading habit is not yet entrenched. Interest in reading students is still lacking to visit the library and read textbook lessons. In the learning phase of the SLP, there are still teachers who are less motivating students to produce work related to the material being studied, e.g. learning poster. In addition, there are still teachers who have not become a model in the classroom during reading habituation activities. Excerpts from the following interviews show the lack of implementation of the SLP."The reading habit of 15 minutes is still much limited to reading fiction books. For non-fiction books or hand books, reading interest in students is still lacking. "Students' portfolio results related to literacy in learning are still lacking."

At the stage of implementation, the procurement of works by the working group of competition and creativity still cannot be implemented properly. The collection of products from each class is still experiencing difficulties due to the lack of student work especially those associated with posters of learning. At the stage of supervision and evaluation, the teacher responds that supervision and evaluation are good enough, although not maximal yet. In each particular activity, supervision and evaluation are always conducted. Things that have not been properly implemented are comprehensive program evaluations. Evaluation results have not been submitted to the school members. Concerning the principal's leadership, the teacher responds that the principal acts as a supportive and facilitative leader. The principal in the lead also demonstrates easy behavior by giving advice and involving teachers and students in decision making. While from the style of leadership, the principal emphasizes on disseminating or dividing responsibilities, empowering the citizens of the school, and cooperating well. The drawback is that the principal sometimes acts too fast, so the teacher needs time to adjust.

For implementations of the design of SLP in the school, that are: 1) need assessment involves in planning, monitoring, and evaluation are not yet established, lack of interest in reading, and lack of infrastructure, 2) planning involves in strengthening school member understanding on SLP, habituation in 15 minutes of reading, development in visiting program to library, reading corner, literacy coordinator, book collection, etc, learning in training teacher related to literacy, procurement of books, 3) organizing involves in recruiting SLT, habituation: literacy coordinator per class, development for TLS, librarians, literacy coordinators, work partners (local libraries, education offices, learning counseling agencies, etc), 4) implementation covers in socialization is done, habituation for literacy coordinator in each class, customization done, library visit, reading corner, development in available reading corner, sijambu, sabusasi, race, book collection increases, Spendayu Literacy Festival, learning for teacher includes literacy and other aspects of the Curriculum 2013 on core activities, 5) monitoring for habituation in doing according to program but there are constraints, development activities have been implemented and need to be improved, in learning every teachers already use the facilities and meet the school policy.

\section{Discussion}

The design of management on SLP developed follows the guidelines developed by Indonesian ministry of education. The design refers to the 3 stages of implementation (habituation, development, and learning). The design process of SLP follows the flow of management functions for the management of a program, one of which is planning, organizing, actuating, and controlling (Hariri, et.al. 2016). Students have a good commitment to the SLP but the involvement of teachers and school member as a literacy model still needs to be developed. The condition is suspected as in the research results of Lastiningsih et.al. (2017). Teachers also consciously describe the benefits and success of the program. Teachers also support the program's implementation. The principal has democratic style as a leader and technical skill, human skill, and conceptual skill 
when design management of SLP (Safaruddin, 2010). This is indicated from how the principal emphasize the dissemination or sharing of responsibilities to the school members, i.e. providing learning environment which support teachers' understanding and awareness of the SLP for students through teacher training related to literacy and cooperating with vice principal and literacy team for implementing all the programs planned in the SLP consistently. Such teacher training, in which other researchers implement as well (see e.g.), were evidently found to be able to help teachers' beliefs and practices become more consistent with what the field considers to be best practices (Kinnucan-Welsch, Rosemary, \& Grogan, 2006; Stephens et al., 2011).

Within the SLP developed in the school, there are some weaknesses found as barriers to implement the program. The authors found that the SLP has lacks at the stage of monitoring and evaluation, in which the results of evaluation has not been well communicated to school members and the principal's mandate about the SLP which cannot be followed fast by the teachers. This is normal since there has not been any similar program implemented in the school in the previous time. These findings illustrate the weakness of teachers' knowledge of the content of literacy. Thus, to improve teachers' literacy knowledge, it should better to provide a teacher professional development which overcome this issue. Stephens et al. applied a model by providing a program called 'school coaching' proposed by Rush (2013) focusing primarily on what they call 'change trainers' and 'content trainers'. Change coaches work primarily with principals, focusing on improving school leadership as a pathway to school improvement, in which in this case is the improvement of literacy among school members, while content trainers work primarily with teachers, focusing on improving disciplined learning. In the SLP presented in this study, the change coaches consist of the principal and vice principal who design and evaluate the SLP periodically, monitor the progress of all the programs designed in the SLP. Meanwhile, the content trainers consist of the School Literacy Team (SLT) where teachers such as English teacher, Indonesian language teachers, and Regional Language teachers are responsible of developing and implementing the content of literacy program. The focus of literacy knowledge that teachers need to develop should be that which should help teachers make curricular decisions that best meet the needs of each and students as readers (Stephens et al., 2011). Stephens et al (2011) exemplified, it can around content which encourage teachers' understanding about the importance of teachers of readers and provide instruction (such as demonstrations, engagements, team teaching, visits to other schools, professional readings) to help the teacher become a more capable teacher of readers.

The role of principal in the SLP was very crucial. This is indicated by the teachers' responses and students' responses toward their principal in this program. Most students (95\%) agree that their principal become a model of the school literacy activities such as exemplifying to read in the first 15 minutes of the lesson activity. Besides, the interviewed teachers also agree that teachers become facilitators and initiator of providing learning environment which support literacy culture in their school. Thus, this is aligned with the various findings related to the successfulness of management at a certain educational institution, in which leaders, which in this case is school principal were the most important people for educational institution management (Augustus et al., 2007; Palasai et al., 2017).

\section{Conclusions}

The results of this study illustrate the SLP management design is quite effective through sequential stages that need assessment, planning, organizing, actuating or implementation, and controlling (monitor and evaluation). It involves all components in schools and management typologies of the principal as a manager tends to supportive-facilitative. Teachers and students tend to respond positively to the SLP although there are several aspects that need to be improved such as the use of technology and the productivity of the work of students or teachers. The lack of this program is on organizing and controlling stage mainly on monitoring and evaluation. This condition requires a professional development of SLP that emphasizes aspects of planning, implementation, and monitoring or evaluation.

\section{REFERENCES}

[1] Armbruster, B. Science and reading. (1992). The Reading Teacher, 46(4), 346-347.

[2] Augustus, E., Longbottom, D., \& Chourides, P. (2007). Managerial leadership for total quality improvement in UK higher education. The TQM Magazine, 19(6), 541-560.

[3] Imam, Ombra A. (2016). Effects of Reading Skills on Students' Performance in Science and Mathematics in Public and Private Secondary Schools. Journal of Education and Learning., 10(2), 177-186

[4] Hariri, H., Karwan, D.H., Ridwan. (2016). Manajemen Pendidikan (Educational Management). Yogyakarta: Media Akademi

[5] Kompri. (2015). Manajemen Pendidikan (Educational Management). Bandung: Alfabeta.

[6] Kisyani,et al. (2018). Panduan Gerakan Literasi Sekolah di Sekolah Menengah Pertama Edisi Revisi. Jakarta: Kemendikbud.

[7] Kinnucan,Welsch, K., Rosemary, C. A., \& Grogan, P. R. 
(2006). Accountability by design in literacy professional development. The Reading Teacher, 59(5), 426-435.

[8] Lastiningsih, N., Muthohir, T.C., Riyanto, Y., Siswono, T.Y.E. (2017). Management of the school literacy movement (SLM) programme in Indonesian junior secondary schools. World Transactions on Engineering and Technology Education (WIETE). Vol.15, No.4.

[9] Martin, M. O., Mullis, I. V. S., Foy, P., \& Hooper, M. (2016). TIMSS 2015 International Results in Science. Retrieved from Boston College, TIMSS \& PIRLS International Study Center website: http://timssandpirls.bc.edu/timss2015/inter national-results/

[10] Miles, M.B, Huberman, A.M. (1992). Analisis Data Kualitatif (Terjemahan). Jakarta: UI-Press

[11] OECD. (2015). Reading Literacy Framework. Retrieved November 12, 2017.https://www.oecd.org/pisa/pisaproduc ts/Draft\%20PISA\%202015\%20Reading\%20Framework\% 20.pdf

[12] Palasai, P., Sirisoponsilp, S., \& Chandrachai. (2017). A. Performance Management Model: A Study in Thai Public Higher Education Institutions, Int. Journal of Economics and Management, 11 (S1), 59-73

[13] Permendikbud. (2015). Peraturan No 23 tahun 2015 tentang penumbuhan budi pekerti. Jakarta: Ministry of Education

[14] Retnaningdyah, Pratiwi, et.al. (2016). Panduan Gerakan Literasi Sekolah di Sekolah Menengah Pertama. Jakarta: Direktorat Jenderal Pendidikan Dasar dan Menengah Kementerian Pendidikan dan Kebudayaan.

[15] Rush, L. S. (2013). Literacy coaching in Wyoming secondary schools: A situational analysis of roles in context. Journal of Literacy Research, 45(3), 267-294.

[16] Syafaruddin. (2010). Kepemimpinan Pendidikan (Educational Leadership). Jakarta: Quantum Teaching.

[17] Siswono, T.Y.E. (2008). Penelitian Pendidikan Matematika. Surabaya: Unipress Unesa.

[18] Siswono, T. Y. E., Kohar, A. W., \& Hartono, S. (2018, January). Designing Tasks to Examine Mathematical Knowledge for Teaching Statistics for Primary Teachers. In Journal of Physics: Conference Series (Vol. 947, No. 1, p. 012008). IOP Publishing.

[19] Siswono, T. Y. E., Hartono, S., \& Kohar, A. W. (2018). Effectiveness of Project Based Learning in Statistics for Lower Secondary Schools. Eurasian Journal of Educational Research, 18(75), 197-212.

[20] Stephens, D., Morgan, D. N., DeFord, D. E., Donnelly, A., Hamel, E., Keith, K. J., ... \& Gallant, D. J. (2011). The impact of literacy coaches on teachers' beliefs and practices. Journal of Literacy Research, 43(3), 215-249.

[21] TIMSS \& PIRLS. (2011). Overview TIMSS and PIRLS. Retrieved November 11, 2017. https://timssandpirls.bc.edu /data-release-2011/pdf/Overview-TIMSS-and-PIRLS-2011 -Achievement.pdf 